\title{
A szegedi Városi Zeneiskola története 1935-1945 között
}

\author{
Pethő Villő - Janurik Márta
}

\author{
Szegedi Tudományegyetem Zenemúvészeti Kar
}

\begin{abstract}
„,Szeged város zenekultúrája nemcsak Szeged város ügye, hanem az országos zenekultúra jelentős tényezője. [...] Ha azonban tekintetbe vesszük, hogy Szeged városát általánosan fejlett kultúrája, egyetemi városi jellege és geográfiai elhelyezése egyenesen predesztinálja a Dél-vidék zenekultúrájának irányítására, úgy megállapíthatjuk, hogy e város zenei életének jelentősége messze túlnő a város határain és a megítélésben Szeged város zenekulturális hivatása éppoly fontos, mint magasabb színvonalon a székesfőváros, vagy az ország egyéb vidéki zeneközpontjainak hivatása. A város zenei életének irányítói teljes mértékben átérzik e kulturális feladat jelentőségét és tervszerú munkával szolgálják nemcsak a helyi, hanem az országos zenekultúra ügyét." - írta 1929-ben Pálfy József, a szegedi városi színház intendánsa és a Szegedi Filharmonikus Egyesület elnöke a Muzsika folyóirat 111. számában, melyet a szerkesztők Szeged zenei életének szenteltek (Muzsika, 1929. 7. o.).
\end{abstract}

A Szeged kulturális életében fontos szerepet játszó és a várost kiemelkedő vidéki zeneoktatási színhellyé tévő 1881-ben megalapított zeneiskola történetének egy rövid, ám rendkívül meghatározó időszakának bemutatására vállalkozik tanulmányunk. Eddig még nem publikált hagyatéki anyagok: levelek, írások felhasználásával szeretnénk a figyelmet felhívni a Belle Ferenc nevével fémjelzett 1935-1944 közötti időszak jelentőségére és eredményeire, melyek a város kulturális életének is fontos évei voltak.

\section{A ZENEISKOLA RÖVID TÖRTÉNETE 1945-IG}

A szegedi zenészekről először egy 1522-ből származó „tized lajstrom” tesz említést, amelyen az adót fizető zenészek nevei szerepeltek. ${ }^{1}$ Az első katonai zenekar a 17. században alakult, emellett a városban fóleg egyházi zenét játszó muzsikusok, együttesek múködtek. Az első olyan zenekart, mely egyházi és világi zenei szolgálatot is teljesített az 1720-as évek elején gróf Nádasdy Lász-

\footnotetext{
${ }^{1}$ Sypos Benedek, Dobos Imre, Lantos György, Cantor Imre.
} 
ló csanádi püspök ${ }^{2}$ szerződtette a városban tett látogatásakor. A kilenctagú zenekar 1724-re vált teljessé, a város ekkor határozta el, hogy külön szállást építtet a tagoknak, ahol zeneoktatás is folyt. Később már csak olyan zenészeket szerződtettek, akik zeneoktatást is vállaltak. A 18. században azonban egyre jellemzőbbé vált a magánoktatás. Az első zeneiskola az 1829-ben megalakult Szegedi Belvárosi Casino kezdeményezésére az 1830-as évek közepén-végén jött létre. $^{3} \mathrm{Az}$ eredeti cél a városi zenekar mellett egy polgári zenekar felállítása volt. Erre alapozva alakult meg aztán a Szegedi Hangászat-oskola, melynek múködését egy 1838-as keltezésú 16 oldalas alapszabályban rögzítették (Kristó és Farkas, 1985), és amelynek fenntartását részvényesek biztosították (Reizner, 1900). Az iskola a levéltári dokumentumok alapján öt évig múködött, majd 1864 újra magániskola lett, végül 1873-ban a fenntartását a város vette át. Az 1879-es árvízben az intézet teljes hangszer- és kottaállománya megsemmisült. Az 1876-tól múködő immár városi intézet teljes hangszer- és kottaállománya megsemmisült az 1879-es árvízben. A Városi Zenede 1880-ban, a város főbb intézményeinek újjászervezésével egy időben nyílt meg egy Széchenyi téren lévő bérházban, Langer Viktor zeneszerzo" ${ }^{4}$ vezetésével. 1882-ben az intézmény a Szeged Szabad Királyi Város által fenntartott közmúvelődési intézetek sorába került. Az 1883-84-es tanévtől az iskola vezetését Szögedi (Roth) Endre ${ }^{5}$, az 1872-től múködő Szegedi Dalárda megalapítója vette át (Gévayné és Kerekné, 2013).

Itt kezdte meg zenei tanulmányait Belle Ferenc, a zenede jogutódja, a Városi Zeneiskola 1935-ben megválasztott igazgatója is. A zenedéről így írt visszaemlékezésében: „,... a városi zenede a templom másik oldalához csatolt épületben volt, bejárata a Templom térrôl nyílott. Ide valóban túlnyomórészt a jobb módú, úgynevezett középosztály gyerekei jártak, de ennek egyik, majdnem fő oka az volt, hogy a zenetanulás az akkori megjelölés szerint nem volt cikk, nem volt pálya, megélhetés. [...] A zenetanulás, mint az általános múveltség kiegészítője, szinte luxusszámba ment." (Belle, 1976. 13-14. o.). Szögedi halála után Király-König Péter ${ }^{6}$ lett az intézmény vezetője. A zeneiskola több szegedi épületben is múködött Király-König igazgatásának kezdetén, majd 1916 szeptemberében költözött az 1881-ben épített Tukats Ferdinánd-féle alapítványi ház

\footnotetext{
${ }^{2}$ Nádasdy László gróf, (1662-1729) 1710-től csanádi püspök. Átmenetileg Szeged székhellyel ő szervezte újjá a törökök alól felszabadult csanádi egyházmegyét.

${ }^{3}$ Érdekes, hogy a zeneiskola megalapítójának nevét és az alapítás pontos dátumát a különböző források különbözőképp adják meg. Reizner János Szeged történetét összegző múvében 1838-as megalapításról írt, alapítóként Miskolczy István aljegyzőt jelölve meg. (forrás: http: //www .bibl . u-szeged.hu/reizner/03/3400.htm, online: 2015. augusztus 1.) Lugosi 1929-ben a Muzsikában megjelentetett Szeged zenei életének történetét összegző munkája (Lugosi, 1929b) szerint a zeneiskolát Tirnauer György regens chori 1836-ban alapította, melynek alapszabályát 1838-ban adták ki. Kristó Gyula és Farkas József munkájában (Kristó és Farkas, 1985) a zeneiskola megalapításának dátuma 1835.

${ }^{4}$ Langer Viktor (1842-1902), zeneszerző és zeneíró.

5 Szögedi (Roth) Endre (1847-1903) főreáliskolai énektanár, karnagy, a Szegedi Dalárda megalapítója és karnagya.

${ }^{6}$ Király-König Péter (1870- 1940) zeneszerző.
} 
felső emeletére. ${ }^{7}$ Bár Szeged város tanácsa már 1908-ban elhatározta, hogy egy Zenepalotát építtet, melyben a zeneiskola is helyet kapott volna (Reizner, 1900), a hangversenyteremként is szolgáló épület megépítésére soha nem került sor. Király-König és később az ôt követő Belle igazgatása idején is próbálták az épületet a zeneiskola céljainak megfelelően átépíteni, további tantermeket és hangversenytermeket alakítottak ki.

\section{Belle Ferenc Életútua}

Belle Ferenc Szegeden született 1891. június 21-én. Középiskoláit a szegedi piarista gimnáziumban, zenei tanulmányait a városi zeneiskolában kezdte meg Daubrawsky Viktor hegedûmúvésznél. 1909-ben egyszerre nyert felvételt a Zeneakadémia (hivatalos nevén: Országos Magyar Királyi Zeneakadémia) hegedú tanszakára, Kemény Rezső osztályába és iratkozott be a Pázmány Péter tudományegyetem jogi fakultására. A zeneakadémián általános zeneelméletre Kodály Zoltán tanította, a zenekari gyakorlatot pedig Hubay Jenő tartotta számára. Az iskolai szünetek is a pályára való készüléssel teltek: „Az iskolai szünetekben Fehér Gizellával, a kitûnő zongoristával folytattuk a kamarázást. Önálló hangversenyekkel szerepeltünk Makón és Hódmezővásárhelyen, de egy-egy kisebb számmal felléptünk rendezvényeken is. 1912-ben a Hungária termében játszottam először zenekarral, Fichtner Sándor vezénylete mellett a Mendelssohn-koncert első tételét." (Belle, 1976. 17. o.). 1914 júniusában kapta meg hegedútanári oklevelét. Az első világháború idején katonai szolgálatot teljesített és főhadnagyi rangot ért el. A háború végeztével 1919 nyarán letette az utolsó szigorlatát, államtudományi doktorátust szerzett és megkezdte a gyakorlást. Fellegvári (Fiedler) Walter gordonkatanárral és Fehér Gizellával zongoratriót alapított.

Még 1918-ban, a Szegedi Filharmonikus Egyesület alelnöke, az egyesület által szervezett szimfonikus zenekar egyik alapító tagja és állandó koncertmestere lett. Az együttes hivatásos és amatőr muzsikusokból, a 46. gyalogezred zenekarának tagjaiból és a Király-König Péter által polgári zenészekből szervezett Szegedi Zenekedvelők zenekarának tagjaiból állt össze. Első hangversenyükön 1919. január 23-án a Tisza Szálló dísztermében Fichtner Sándor vezényletével álltak színpadra (Pappné, 2009).

1919 szeptemberében Szeged város a Király-König vezette Városi Zeneiskola hegedútanárává nevezte ki. Belle tanári munkája mellett is tevékenyen részt vett Szeged zenei életében: rendszeresen lépett fel kamaraprodukciók tagjaként, a zenekar hangversenyein koncertmesterként. Jó kapcsolatokat ápolt a szegedi értelmiségiekkel, jó barátságban volt Balázs Béla családjával, Fleischer Antal és Fricsay Ferenc karmesterekkel, az 1921-ben Szegedre költöző kolozsvári egyetem

${ }^{7}$ A Zeneiskola 1916-os beköltözését követően többször alakították át az épület helységeit az oktatási intézmény számára. Ma is ez az épület ad otthont a város zenei közép- és felsőoktatási intézményeinek: a Vántus István Gyakorló Zenemúvészeti Szakközépiskolának és a Szegedi Tudományegyetem Zenemúvészeti Karának. 
zenekedvelő professzoraival pedig rendszeresen muzsikált együtt (Belle, 1976). ${ }^{8}$ Az 1934-35-ös tanévben igazgatóhelyettesként az 1934 szeptemberétől betegszabadságon lévő Király-König Péter helyett ő látta el az igazgatói teendőket, az iskola értesítőjét is ő adta közre. Bellét a város végül 1935. október 31-én nevezte ki az intézmény igazgatójává. Belle sokat tett a Király-König Péter idején már országosan elismertté váló zeneiskola pedagógiai és szakmai megújulásáért. Igazgatói és tanári teendői mellett továbbra is részt vett a város zeneéletében kamaramuzsikusként, és a Szegedi Kamarazenekar koncertmestereként.

A háború alatt többször teljesített katonai szolgálatot. 1944 márciusában, Szeged német megszállásakor négy gyermekével és feleségével elhagyta a várost. Először Kalocsára majd Faddra, végül a Tolna megyei Szedresre költözött. Itt 1944 decemberétől szolgálatot is teljesített, 1945 áprilisáig segítette az szovjet hadsereg ellátását, ellenőrizte a község környéki gazdasági munkák elindulását. Szegedre 1945 májusában tért vissza családjával. A zeneiskola igazgatójának 1944 novemberétôl Kollár Pált nevezték ki. Belle visszatérése után 1947-ig a hegedútanárként múködött az intézményben, majd ezt követően Orosházán és Makón tanított. A zeneiskolákban végzett munka mellett Belle tagja volt az 1945ben már Vaszy Viktor vezetésével koncertező színházi zenekarnak, majd ennek megszûntével a színházi zenekari tagokból, zenetanárokból és amatőrökből megalakított Paulusz Elemér vezette Szegedi Filharmonikus Zenekarnak. 67 évesen ment nyugdíjba. 1977. december 20-án bekövetkezett haláláig rendkívül aktív életet élt: a Tábor utcában múködô zeneiskolában helyettesítő tanár volt, emlékiratain, többek között a Városi Zeneiskola történetén dolgozott. ${ }^{9}$

\section{A ZENEISKOLA PEDAGÓgIAI PROGRAMJA}

A zeneiskola korábbi vezetői, Szögedi (Roth) Endre és Király-König Péter egyaránt sokat tettek azért, hogy az intézmény a város, a régió és az ország zenei és kulturális életében meghatározó, magas múvészi színvonalat képviselő intézménnyé váljék (Kerek, 2003). Ezt a munkát folytatta Belle Ferenc, akinek szinte valamennyi, az ô igazgatása idején kiadott értesítőben jelent meg a zeneiskola társadalmi és kulturális szerepéről, az iskola pedagógiai törekvéseiről szóló cikke, rövid írása. ${ }^{10}$ Az első, 1935-36-os tanévről szóló értesítőben Belle három pontban összegezte a zeneiskolák legfontosabb feladatát: „A zeneiskolának három feladata van. Az első: szakszerúen előkészíteni és képezni azokat a nagytehetségú növendékeket, akiket adottságuk a zenei pályára vonz és predesztinál; a második: olyan jó amatôr muzsikusokat képezni, akik mint kamarazenészek és zenekari tagok a gyakorlati zeneéletnek hasznos és lelkes tagjai lehetnek; a

\footnotetext{
${ }^{8}$ A Kamarazene Kör később, már zeneiskolai igazgatósága alatt újból megalakult, és rendszeresen szervezett koncerteket, később hangversenysorozatokat is nagy sikerrel.

${ }^{9}$ A Somogyi Könyvtárban fellelhetôek ezek az írások.

${ }^{10}$ A korábbi értesítőkre ez nem jellemző, melyek szinte kizárólag csak az intézményhez köthető statisztikai adatokat közöltek.
} 
harmadik: zeneélvező, zenefogyasztó közönséget nevelni." (Belle, 1936b. 7. o.).

Összevetve egy korábbi, 1923-ból származó értesítőben megfogalmazott képzési célokkal (a tanulók színvonalas képzése, a kiemelkedően tehetségesek felkészítése az akadémiai osztályok elvégzésére) itt új elemek is kerültek be a zeneiskola nevelési céljai közé. Az első, hogy a helyi (amatőr) zenei együttesekben való közremúködésre alkalmas tudással kerüljenek ki az iskolából a diákok. Vagyis elsősorban az iskola múködését segítő város, illetve régió kulturális igényeit kell a zeneiskolának kiszolgálnia. A második új elem ezzel összefügg: ki kell nevelni azt a közönséget, aki akár a helyi zenészek, akár magas múvészi színvonalat képviselő hangszeres és énekes múvészek hangversenyeit látogatja majd. Belle szerint a feladatok közül a vidéki zeneiskolákra - így a szegedire is - két fontosabb teendő hárult: jó amatôr muzsikusokat nevelni, illetve „a zenemúvelés képességét és szeretetét a társadalomba belevinni" (Belle, 1936b. 10. o.). Ehhez a zenetanárok tervszerú szakmai és pedagógiai munkájára és a növendékek kitartására egyaránt szükség volt. Érdekes azt látnunk, hogy a mai nyelvhasználatban meglehetősen negatív jelentést hordozó amatőr kifejezés mit is jelentett ebben az időben: Belle idejében az számított jó amatőr muzsikusnak, aki 10-12 évi zenetanulás után „... legalább a második-harmadik akadémiai osztályt, a Zenemúvészeti Főiskola kívánalmait megközelítő alapossággal és előképzettséggel elvégezte" (Belle, 1936b. 7. o.).

Belle ugyanebben az írásában utalt arra, hogy Szeged város vezetőinek megbízásából egy, a zeneiskola megújítására vonatkozó, átfogó tervezetet is készített, mely „a legilletékesebb hatóság elé került” (Belle, 1936b. 7. o.). A Belle-hagyatékban fellelhető egy levél, melyen sem aláírás, sem dátum nem szerepel, a címzettje pedig Hóman Bálint dr., magyar királyi vallás és közoktatásügyi miniszter. A szövegben Belle említi az 1934-es középiskolai reformot, vélhetően a levél ezután keletkezhetett, elképzelhető, hogy erre a levélre tett utalást az értesítőben is. A levél pedig nem más, mint egy több lépésből álló reformterv a zeneiskolák tanárainak szakmai továbbképzésére, melyre azért is lehetett szükség, mert a zeneiskolák helyzete nem változott. Bár átfogó reformra Belle nem látott esélyt, úgy gondolta, hogy tervezetét a hasonló fenntartói háttérrel rendelkező egyetemi városokban: Debrecenben, Pécsett és Szegeden lehetne bevezetni. A tervezetben három pontban jelölte meg a szükséges változtatásokat: (1) speciális didaktikus ellenőrzés; (2) pedagógiai tanulmányok; (3) múvészi továbbképzés. Az elsô pontban a kijelölt vizsgabiztos látogatása helyett egy évente megszervezett, zenakadémiai tanárokból álló szakfelügyelői bizottsági látogatást tartott szükségesnek. A második pontban jelölt pedagógiai tanulmányokat Belle szerint a vidéki zenetanárok a Zeneakadémián végezhettek volna. Mivel sok okleveles tanár csak a tanárképző osztályokat végezte a Főiskolán, ezért indoklása szerint ilyen rövid idő alatt és csak egy tanár tanítását, módszereit látva ezek a fiatal tanárok nem nyerhettek a tanításról általános, átfogó képet. Tervezetében minden év májusában nyílt volna lehetőség a vidéki tanárok számára a Főiskolán hospitálni. A terv legkidolgozottabb pontja a 
harmadik, melynek célja a zenetanárok és a megfelelő előképzettséggel bíró zenemúvészek rendszeres továbbképzése. Programjában Belle az augusztus 2. és 23. közötti időszakban egy magyar nyaralóhelyen megtartandó tanfolyamot „szabad iskola”-ként írta le, melynek elvégzéséről a zenetanárok végbizonyítványt kaptak volna. A résztvevők számára hetente öt napon keresztül legalább négy óra elfoglaltságot tervezett, a részvétel feltételeként pedig legalább két, előadásra alkalmas zenemúvel való foglalkozást írt elő. A tanfolyam vezetőjének irányításával ezeken a múveken keresztül a legújabb technikai és pedagógiai kérdések megvitatására kerülhetett volna sor. E múvek hangversenyen való bemutatását is fontosnak tartotta, amelyre a kurzus második felében nyílt volna lehetőség. A tervezethez részletes költségvetés is kapcsolódott.

Bár a tervezet országos szinten nem valósult meg, Belle Ferenc próbálta elképzeléseit az igazgatása alatt álló szegedi zeneiskolába átültetni. Az 1937-38-as tanév eredményeit összegző értesítőben a következőket írta Újabb iskolatípus felé címú cikkében: „,... meg kell, hogy változzék az általános felfogás a zeneiskolák feladatáról, ne egy „,tessék-lássék dilettantizmust fejlesztő intézetet, hanem olyan szakiskolát lásson, ahol nehéz, komoly munkával ugyan, de maradandó értékú tudást és múveltséget lehet és kell szerezni." (Belle, 1938b. 5. o.). A zeneiskola épületének 1939-es felújítása új program megfogalmazására is lehetőséget adott. Az 1939-es tervekben között az új tanszakok bevezetése, a hangversenyek számának növelése mellett a zenetanárok számára pedagógiai előadásokat szeretett volna tartani, valamint kiemelt feladatként jelölte meg a zeneiskola tankerületi központi szerepére való felkészülést is ${ }^{11}$ (Belle, 1939b). A zeneiskolában már korábban is figyelmet fordított a tanárok szakmai és pedagógiai továbbképzésére. Az 1936-37-es tanév folyamán tervezték, hogy az intézmény szakkönyvtárát pedagógiai és zenepedagógiai munkákkal bóvítik ${ }^{12}$, az aktuális kérdéseket, a legújabb szakirodalmat és gyakorlati módszereket pedig előzetes munkaterv szerint megvitatják a tanári megbeszéléseken. 1937 januárjában a tanári karból többen is részt vettek az országos szakfelügyelő kezdeményezése nyomán megrendezett konferencián, melyen a zeneiskolai tanítás aktuális kérdéseit vitatták meg (Belle, 1937). 1938-ban a tantestület belépett a Magyar Nevelők Egyesületébe, ugyanekkor részt vettek az egyesület békéscsabai vándorgyưlésén is, a későbbiekben pedig szorosabb együttmúködést is terveztek (Belle, 1938b).

\section{A ZENEISKOLAI KÉPZÉS SZERKEZETÉNEK VÁLTOZÁSAI}

A zeneiskolai képzés szerkezetét már Király-König igazgatása alatt többször finomították. A legnépszerúbb zongora és hegedú szakokon a teljes képzés 9, később 11 évfolyamon keresztül folyt: az előkészítő évet követően hat további

\footnotetext{
${ }^{11}$ Az értesítő tanúsága szerint a korabeli kultuszminisztérium egyik terve volt, hogy a szegedi zeneiskolát tankerületi központtá teszik.

12 Lugosi Döme 1929-es jelentésében a zeneiskola könyvtárában fellehető 40 db szakkönyvről írt.
} 
évfolyamot elvégző diákok közül a legtehetségesebbek ún. kimúvelési osztályokban folytathatták tanulmányaikat. A mélyvonós, fúvós hangszerek és a magánének képzési terve nagymértékben eltért ettől ${ }^{13}$. A korábban már említett zongora és hegedú szakok képzési szerkezete Belle Ferenc igazgatóságának kezdetén, 1935-ben a következő volt: az 5 alsó és az azt követő 5 középosztály sikeres elvégzése után a tehetségesnek bizonyuló növendékek 4 akadémiai osztályban tökéletesíthették tudásukat. A kimúvelési és akadémiai osztályok elvégzése után több növendék nyert felvételt a Zeneakadémiára, akik tanulmányaik végeztével múvészképesítést kaptak. Azok, akik tanulmányaikat Szegeden folytatták, a kimúvelési osztályok elvégzése után, vizsgadíj megfizetése mellett a Zeneakadémián vizsgázhattak és zenetanári oklevelet szerezhettek. Már Király-König Péter igazgatása előtt is fontos volt a zenede vezetői számára, hogy tananyagainak közzétételével fenntartóját és a város lakosságát meggyőzzék arról, hogy az intézmény szakmailag és pedagógiailag megfelelő oktatást nyújt. Király-König évekkel megelőzve a minisztérium előírásait, az általa tanított tantárgyak - elmélet, szolfézs, összhangzattan, formatan és moduláció - tananyagát a zeneakadémiai gyakorlatnak megfelelően változtatta meg. Az 1917-18-as tanévtől kezdődően bevezetett felvételi vizsgával biztosítani szerette volna, hogy zenei képzésre valóban alkalmas diákok kezdjék meg tanulmányaikat (Kerek, 2003).

A tananyag folyamatos megújítására Belle is törekedett. Az 1936-37-es tanévben a zongora tanszakon bevezette a Zeneakadémia megújított tantervét, a következő tanévtől tervezték, hogy a többi tanszak képzése is követi a zongora tanszaki változásokat. Az 1937-38-as tanévben az osztályozásban is követték a zeneakadémiai gyakorlatot: „,... rátértünk a zenemúvészeti főiskola ötfokú szabályozó rendszerére, amelyben a jeles már igen jó kalkulus, a kitûnő pedig a ténylegesen kiváló növendékek szorgalmának elismerése." (Belle, 1938b. 4. o.). A Belle-időszakban is többen tettek magánvizsgát a Zeneakadémián, illetve nyertek felvételt annak osztályaiba, melyek eredményeiról minden értesítóben beszámoltak.

A zeneiskola már korábban is több szállal kapcsolódott a zeneoktatás korabeli csúcsintézményhez, a Zeneakadémiához. Michalovich Ödön, a Zeneakadémia igazgatója, ${ }^{14}$ az ott végzett tehetséges növendékeket beajánlotta a jelentősebb zeneiskolák élére. Király-König Péter is így került Szegedre. Belle Ferenc, és korábbi szegedi hegedútanára, Daubrawsky Viktor szintén a Zeneakadémián szerezte diplomáját.

A Városi Zeneiskola a jelenlegi zeneiskolai rendszerrel összehasonlítva egyfajta átmenetet képviselt, mindamellett, hogy alapfokon képezte a kezdő növendékeket, a további osztályokban középfokú, majd az akadémiai osztályoknak

${ }^{13}$ Bővebben lásd még: Gévayné Janurik Márta és Kerekné Fekete Éva (2013): A Zenedétől a Zenemüvészeti Karig. Fejezetek a szegedi zeneoktatás történetéből dokumentumok és képek tükrében. Litofilm Nyomda, Szeged, 18. o.

14 1887-1919-ig állt Mihalovich Ödön (1842-1929) a Zeneakadémia élén. 
köszönhetóen a képzés szerkezetében és tartalmában is kapcsolódott a Zeneakadémiához. A zeneiskola vezetésének azon törekvése, hogy a képzés színvonalában közelítsen a budapesti intézethez, nemcsak a jól képzett muzsikusok belső igényéből is következhetett, hanem a vidéki intézmény gazdasági érdeke is volt. A zeneiskola számára ugyanis nemcsak az 1925-1934 között múködő dr. Baranyi János magán zeneiskolája de az önállóan múködő magántanárok is konkurenciát jelentettek (Lugosi, 1929a).

\section{A ZENEISKOLA TÁRSADALMI SZEREPE}

Belle Ferenc, akárcsak elődei, pontosan tudta, hogy csak egy olyan intézmény maradhat fent és kaphat folyamatos anyagi támogatást a várostól, amely minél több és minél eredményesebb növendéket nevel ki, és amely aktív, akár meghatározó résztvevője a város és a régió kulturális életének.

Jól látta, hogy a város, sőt a régió zenei életében egyaránt fontos szerepet játszhat az intézmény. Az értesítőkből, de más írásaiból is kiderül, hogy tervszerúen igyekezett erre a szerepvállalásra is felkészíteni az iskolát és zenét tanító kollégáit. Belle egy, a tanári karhoz intézett beszédében ki is tért rá, hogy az intézmény fenntartása milyen nagy megterhelést jelent a városnak, és annak érdekében, hogy továbbra is támogatást kapjanak, még eredményesebben és még többet kell dolgozniuk. ${ }^{15}$ A zeneiskola sikerességének egyik titka a szülők megnyerése volt. Az 1936-37-es tanévről szóló értesítőben írnak arról, hogy a szülőket fel kell világosítani, miként gyakorolhatnak a növendékek minél helyesebben, gazdaságosabban, egyúttal eredményesebben otthon. A szülői értekezleten emellett nemcsak a gyakorlásról szóltak, de a tanári megbeszélések pedagógiai témáit is megosztották. A következő, 1937-38-as tanévben az új bizonyítvány, az index bevezetésének is az volt a célja, hogy így a növendékek tanulmányairól, előmeneteléről, szorgalmáról minél áttekinthetőbb képet adjanak (Belle, 1938a). Emellett szülőket is várták azokra a zeneismertető előadásokra, amelyeket 1936-37-es tanévtől kezdődően „tervszerúen” szerveztek a növendékek számára. A zeneismertető előadásokat az igazgató bevezetője nyitotta, majd az előadások végén a tanárok értekezletet tartottak. Az 1937-38-as tanév zeneismertető előadásai: Dr. Magyariné Vesztényi Gizella a zongoratanszak első ötévi tananyagából játszott gyakorlatokat és darabokat, melyekhez Antos Kálmán, az elméleti tárgyak oktatója tartott magyarázó előadást. Jónásné Baranyi Ilona A zongora technikája és a billentés címú tanulmányát olvasta fel. Perényi Pál „Az iskola a növendékek és a szülők viszonya" címmel tartott előadást. Erdélyi János a hegedútanszak első hatévi anyagából adott elő múveket, melyeket pedagógiai és zenei magyarázatokkal látott el. Antosné Simkó Mária zongoratanár Chopin életéről és múveiről tartott előadást, Kollár Pál Chopin múveket játszott (Belle, 1938a. 13. o.).

\footnotetext{
${ }^{15}$ Belle hagyatékában található írás dátum és cím nélkül.
} 
Az értesítőkből kiderül, hogy mindemellett a szegény sorsú, tehetséges diákok támogatását is fontosnak tartották. Az iskola a várossal egyetértésben minden évben meghatározott számú növendéknek nyújthatott teljes, illetve fél tandíjmentességet. Az 1936-37-es tanévben a tanári kar segélyegyletet hozott létre, amely a szegény, de tehetséges növendékeket hangszerrel, hangszertartozékokkal vagy kottákkal támogatta (Belle, 1937). Többször szerveztek olyan koncerteket, melyek teljes bevételét a szegény diákok támogatására fordították.

A zeneiskola számára fontos volt, hogy a diákjai nyilvános hangversenyeken is bemutathassák tudásukat. ${ }^{16}$ Ezeket több helyszínen tartották: a zeneiskola nagytermében, a Tisza Szálló dísztermében vagy az Ipartestület márványtermében, de a magánének tanszak növendékei rendszeresen szerepeltek az Alsóvárosi Kultúrházban és a Szegedi Nemzeti Színházban is músorukkal. A zeneiskola kórusa és zenekara is több rendezvényen múködött közre. Lugosi Döme megjegyzi, hogy az 1920-as években jellemzően a városban megrendezett hangversenyek látogatottsága elég gyér volt, csak a „világsztárok”, illetve a Szegeden ismert és elismert múvészek koncertjeire ment el számottevő hallgatóság (Lugosi, 1929a).

Ezért is volt figyelemre méltó az a törekvés, hogy a zeneiskola tanárai az intézmény falain belül önálló hangversenyeken lépjenek fel. Az 1934-35-ös tanévben szervezték meg a Kamarazene Kört, melynek már az első évben négy hangversenye volt a zeneiskola nagytermében, ezeket a hangversenyeket az ezt követő években is rendszeresen megrendezték. Később a háborús években a hangversenyélet megszervezésében új utakat kellett keresni.

Az 1940-41-es értesítőben megjelent rövid tanulmányában Belle Ferenc arról írt, hogy a gazdasági és politikai változásokhoz a hangversenyéletnek is igazodnia kell. A közép-európai országok és Budapest gyakorlatát követve szükség lenne arra, hogy minél szélesebb tömegek számára olcsó és kedvelt hangversenyeket szervezzenek, melyeken keresztül a „kisfizetésú társadalom” vagy a munkásság köréből verbuválódott közönség számára nyújtanának színvonalas szórakozási lehetőséget (Belle, 1941b). Ezzel a céllal jött létre még 1934-35-ös tanévben a korábban említett Kamarazene Kör. 1941-ben ugyanezzel a céllal szervezték meg a szegedi Népmúvelési Bizottsággal együtt első bérleti hangversenysorozatukat részben meghívott múvészekkel, részben a zeneiskola tanárainak közremúködésével, melyre minden bérlet már elővételben elkelt.

A zeneiskola tanárai nemcsak az intézmény keretein belül szerepeltek szólistaként vagy kamarazenészként hangversenyeken, rendezvényeken. "A zeneiskolai tantestület tagjai tudatában vannak annak, hogy többszöri szereplésükkel és többoldalú tevékenységükkel együttesen szolgálják a város zeneéletének, a zeneiskolának, egyes társadalmi vagy kulturális célú megmozdulásoknak érdekeit éppúgy, mint saját múvészi érvényesülésüket, ezért az elmúlt év folyamán több ízben szerepeltek iskolán kívül. .." - adta hírül az 1942-43-as tanévról készített értesítő (Belle, 1943b. 5. o.). A tanárok közül többen egyébként - maga Belle

\footnotetext{
${ }^{16}$ A hangversenyek músorát az 1942-43. tanévig részletesen közlik az értesítők.
} 
is - más posztokat is betöltöttek, melyek szintén szoros kapcsolatban voltak a szegedi zenei élettel. Belle Ferenc a zeneiskola tanáraként, később igazgatójaként egyúttal a Filharmóniai Egyesület egyik alapító tagja és koncertmestere is volt. Antos Kálmán zeneszerzô, orgonista pedig a szegedi dóm orgonistája és karnagya, valamint a Szegedi Dalárda és Oratóriumegyesület valamint a Szegedi Polgári Dalárda karnagya volt és emellett tanította a zeneiskolában az elméleti tárgyak nagy többségét.

Az értesítők szerint a zeneiskola nagytermében több szegedi zenei együttes is rendszeresen próbált: nemcsak a Kamarazene Kör, melynek az iskola tanárai is aktív tagjai voltak és az Antos vezette két dalárda, de a Filharmonikus Egyesület, az Egyetemi Énekkar és a Szegedi Városi Énekkar is itt tartották próbáikat.

Már a Király-König idején kiadott zeneiskolai értesítőkből kiderül, hogy nagy hangsúlyt fektettek a magyar szerzők múveinek tanítására és előadására. Rendszeresen közölték, mely szerzők hány múvét tanulták és játszották a diákok. Az 1930-as tanévben például a König vezette intézmény diákjai harmadik évfolyamtól kezdődően összesen 293 múvet tanultak magyar szerzőktől. ${ }^{17}$ Ezt a „hagyományt" Belle Ferenc idején is folytatták. Rendszeresen játszották többek között Antos Kálmán, Bartók Béla, Dohnányi Ernő, Hubay Jenő, Kacsóh Pongrác, Kazacsay Tibor, Kodály Zoltán, Lavotta Rezső, Liszt Ferenc, Molnár Antal, Popper Dávid és Weiner Leó múveit. A zeneiskola hangversenyein is gyakran játszottak magyar és ezen belül szegedi szerzőktől is. 1941 májusában a Király-König Péter emlékére szervezett koncerten kizárólag a mester múvei szólaltak meg (Belle, 1941b.4. o.).

\section{A ZENEISKOla tANSZAKAi Belle VeZETÉSE IDEJÉN}

Király-König Péter igazgatása alatt a népszerû zongora- és hegedûszakok mellett évről-évre további tanszakok indultak. Az 1907-08-as tanévtől kezdődően már gordonka, gordon, fuvola, klarinét, kürt és magánének szakokon egyaránt folyt az oktatás (Kerek, 2003). Az első világháború kitörésekor - mint arról már korábban írtunk - azonban a tanárok szolgálatteljesítése miatt a zeneiskola fúvós és nagybőgő osztályain a tanítás szünetelt. A kötelező és választható melléktárgyak struktúrája Király-König Péter igazgatása alatt szintén sokat változott, bővült. Fontos szerepet kapott a karének, a zenekari tanszak, a kamarazene melléktanszak, de lehetőség volt zongorát és éneket is melléktanszakként tanulni. Az elméleti tárgyak között elméleti alapismereteket, összhangzattant, zenetörténetet tanultak a növendékek. 1930-ban König az esztétika melléktárgyat is bevezette, melynek előadásait ő maga tartotta (Kerek, 2003). A háborús éveket követően, az 1920-as évek végén a zeneiskola még mindig csak négy tanszakon: zongora, hegedú, gordonka és magánének szakon képezte a növendékeket. A kötelező és

\footnotetext{
${ }^{17}$ König Péter (1931): A szegedi Államilag Segélyezett Városi Zeneiskola Értesítője. 1930-1931. Szeged Városi Nyomda és Könyvkiadó R. - T. Szeged.
} 
választható melléktanszakok száma nőtt ebben az időszakban, elméletet, solféget, összhangzattant, formatant, modulációt, zenetörténetet tanulhattak, valamint karének, kamarazene és zenekari osztályokba járhattak a tanulók (Lugosi, 1929).

Belle Ferenc igazgatása alatt a tanszakok száma a korábbiakhoz képest kis mértékben bővült. Az 1934-35-ös tanévtől kezdődően, a korábbi zongora, hegedú, gordonka és magánének szak mellett nagybőgő és elmélet szakokon folyt a tanítás. A gordonszakosok létszámának növekedését segítette elő, hogy 1934 és 1943-között teljes díjmentességet élveztek, az elméletszakosokat pedig kevesebb tandíj megfizetése mellett „kültag”-ként tartották számon; számuk elenyésző volt a többi tanszakéhoz képest. Az első világháború kezdetéig fúvós hangszereket $^{18}$ is találunk a tanszakok között. A háborús években ezek a tanszakok megszúntek, a későbbiekben a fúvós hangszerek oktatását sem Király-König Péternek, sem az ôt követő Belle Ferencnek nem sikerült bevezetnie. Az 1936ban közreadott értesítőben Belle már kiemelte, fontos feladata az intézménynek, hogy újra induljanak a fúvós tanszakok, megfelelő zenészutánpótlást biztosítva a városban múködő zenekarok, kamaraegyüttesek számára. Ez azonban csak terv maradt, hiszen az 1937-ben és 1939-ben kiadott értesítők programszerú cikkeiben a fúvós tanítás újraindításának tervéról éppúgy olvashatunk. Ezen a téren változás csak a második világháború utáni években következett be (Gévayné és Kerekné, 2013).

A Belle-korszakban a választható és kötelező melléktárgyak köre nem változott lényegesen. Az elméleti, összhangzattani osztályok mellett megmaradtak a formatan és esztétika tantárgyak, a zenetörténet oktatása két kurzus, a magyar és egyetemes zenetörténet formájában történt. Emellett karének (kezdő és haladó), kamarazene és zenekari osztályok indultak még. Újdonság volt azonban, hogy 1936-37-es tanévben heti két alapismereti órát tettek kötelezővé a kezdő növendékek számára. Az intézkedés szükségességéről a következőképpen nyilatkozott a melléktárgyakat oktató Antos Kálmán: „A zeneiskoláknál bevezetett elméleti, összhangzattani, formatani, történeti stb. órák nem akadémikus nagyképúségből létrehozott felesleges külön megterhelést jelentenek a növendéknek, ellenkezőleg: a zenei nevelés kizárólag akkor lehet célravezető, ha a hangszertanulással párhuzamosan gondoskodás történik a zenei hallás és ritmusérzék rendszeres fejlesztéséről, valamint a zenével kapcsolatos ismeretek módszeres elsajátításáról.." (Antos, 1937. 14. o.).

\section{KISGYERMEKEK ZENEI NEVELÉSE A ZENEISKOLÁBAN}

A zeneiskolának nyilvánvaló érdeke volt, hogy minél több diákot iskolázzon be és azok minél hosszabb ideig tanuljanak zenét. Ezért a legfiatalabb korosztályt is szerették volna megnyerni: először az 1934-35-ös tanévről szóló értesítőben említik a 4-7 éves korú gyerekek számára szervezett „zeneovodai” foglalkozáso-

\footnotetext{
${ }^{18}$ Fuvola, klarinét, kürt, amely hangszereket katonazenészek tanítottak.
} 
kat. A cél az volt, hogy még az iskolába kerülés előtt megszerettessék a zenét a gyerekekkel, ha már ekkor kiderül, hogy a gyermek tehetséges, nagyobb eséllyel marad az intézet növendéke. Az előzetes tanulmányoknak köszönhetően a később iskolába kerülő gyermek számára pedig már nem olyan megterhelő a hangszertanulás, mintha egyszerre két iskolában kezdi meg tanulmányait. A foglalkozásokat Simkó Mária zongoratanárnő, az elméleti tárgyakért felelős Antos Kálmán felesége tartotta, aki a zeneóvodáról szóló cikkben kiemelte: „Tanulásról szó sincs, mégis a kis apróságok sok tudást sajátítanak el, mint azt az első év eredménye igazolta s közben mindegyikről meg lehet állapítani, milyen tehetséggel van megáldva hallás, ritmusérzék, emlékezet, fizikai adottság stb. szempontjából s azt, hogy milyen hangszer tanulására alkalmas, hajlamos." (Simkó, 1936. 12. o.). Ennek ellenére, a foglalkozások inkább hasonlíthattak a mai zeneiskolai előkészítőre: énekeltek, hallás- és ritmusfejlesztő gyakorlatokat végeztek, hangszertanuláshoz szükséges mozgásokat, hangjegyeket tanultak. Az értesítőkben is gyakran szerepelt a „zeneóvoda” mellett a ,zenetanuláshoz előkészítő iskola” vagy csak „előkészítő iskola” elnevezés. A foglalkozások októbertől májusig tartottak, a májusi növendékhangversenyeken pedig rendszeresen tartottak a csoportok „zene-óvodai tanóra bemutatót”. Bár az első években sok jelentkező volt ebbe az osztályba (1936-37-es tanévben 27-en, az 1937-38-as tanévben 13-an), többen kimaradtak (1936-37-es tanévben 10, 1937-38as tanévben 9 növendék). Az 1937-38-as tanévről összeállított értesítőben Belle Ferenc a következőkre mutatott rá: „... fontos, hogy felismerje a társadalom, milyen nagy szükség van a gyermekek zenetanulására - ez vezet komolyabb eredményre." lényegesen alacsonyabb volt (Belle, 1938b. 4. o.).

Az 1938-39-es tanévben nem indítottak zeneóvodai csoportot. Ezután új tanárral és új elvek mentén szerették volna újrakezdeni a foglalkozásokat. Az 1938-39-es értesítőben olvasható cikkből, amely az új elképzeléseket volt hivatott bemutatni úgy tûnik, sokkal inkább az iskolai tanításra emlékeztető előkészítőt szerettek volna létrehozni, mintsem játékos órákat óvodás korú gyerekek számára. Tölgyesiné Renyé Anna énektanárnő, akit a város óradíjas tanárként alkalmazott a zenei előkészítő foglalkozások megtartására, „Zeneelőkészítő iskola a legújabb pedagógiai elvek alapján" címú írásában foglalta össze pedagógiai elképzeléseit és a csoportokkal kapcsolatos terveit. Renyé számára nyugat-európai, amerikai intézmények, valamint az ebben az időben Budapesten múködő hasonló csoportok, és a Debrecenben létrehozott „zeneelőkészítő mintaiskola” jelentett követendő példát. Ő maga 1938-ban részt vett Budapesten a Magyar Énekoktatók Országos Egyesületének szervezésében megrendezésre kerülő Fritz Jöde német zenepedagógus által tartott előadássorozaton, amely a gyermekek zenei neveléséhez kapcsolódó német elképzeléseket mutatta be, és amely szintén nagy hatással volt rá. „Vázolt tanulmányozott módszerek alapján, tovább Molnár Imre és Molnár Antal Zenemúvészeti Főiskolai tanár urak támogatásával gondolom egy ilyen - a rendes iskolán kívül a múvészi nevelés minden ágát felölelő, mégis a zenei előkészítést hangsúlyozó - zeneóvoda kialakítását és Szegeden való beve- 
zetését." - írta ${ }^{19}$ (Tölgyesiné, 1939. 16. o.). A zeneóvodába szeptemberben lehetett jelentkezni, a tanítást különböző korcsoportokban - 4-5 évesek, 6-8 évesek; 8-10 évesek; 11-15 évesek -, viszonylag magas óraszámban, heti háromszor két órában tervezték megindítani. Ezt követően a zeneóvoda sorsáról, programjáról nem tudunk sokat. Szintén a témához kapcsolódik az 1940-41-es tanévet összegző értesítőben megjelent tanulmány. Belle „A gyermek és a zene” címú írása a zenetanulás gyermekkorban való megkezdésének szükségességére hívta fel a figyelmet. Egyúttal kitért arra, hogy a gyermekek különböző képességeinek fejlettsége között nagy különbségek lehetnek, és e képességek közül a zenei képességek fejlettségének mértéke nehezen ellenőrizhető: „A gyermek képzetei csaknem minden területen könnyebben ellenőrizhetők, mint a hangok, a zene területén. [...] A zenében áll a legnagyobb nehézség előttünk..." (Belle, 1941c. 5. o.) A gyermekek zenei nevelése szempontjából két kiemelt feladatot fogalmaz meg: „Az első az éneklés, amely karének és bizonyos hallásvizsgáló foglalkozás. Ez egy külön probléma, amelyre vonatkozólag Kodály Zoltán dr. korszakalkotó irányelveket tartalmazó tanulmánya kell, hogy átalakítólag hasson." (Belle, 1941c. 6. o.) Az aktív énekes és hangszeres zenélés mellett a zene passzív befogadását is tervszerúen emelné a zenei nevelésbe: „A második rész a hangszeres zenével való megismerkedés passzív hallgatás vagy tanulás útján. [...] Tapasztalat szerint az utóbbi az elhanyagoltabb terület..." (Belle, 1941c. 6. o.) A zenei előkészítő osztályok kiépítésének kísérlete nem volt hosszú életú, az 1940-41-es értesítőben még olvasható a beiratkozás időpontja, a tandíj összege, de semmi további adatot nem közölnek a zeneóvodához kapcsolódóan. Az 1941-42-es és az 1942-43-as tanévekről szóló értesítőkben már a beiratkozás lehetőségéről sem tesznek említést. Az értesítőkben követhető, hogy zeneóvodai csoport csak a második világháborút követően, 1945-ben indult újra.

\section{A ZENEISKOLA TANÁRI KARA}

„A modern zeneiskola megteremtésével” - írja Lugosi a zeneiskola 1880-as alapítására célozva - „a tanerők felszabadultak a zeneszolgáltatási kötelezettség alól és így teljes idejüket a zeneoktatás ügyének szentelhették. Ennek megvolt az az áldásos hatása, hogy a zenei múvelődés jobban terjedt, de megvolt az a hátránya, hogy a zenekari múvek bemutatása háttérbe szorult" (Lugosi, 1929a, 29. о.).

1929-ben a Lugosi-jelentés közreadásának idején a zeneiskola tanári karába az igazgató Király-König Péteren kívül kilenc rendes tanár, egy helyettes és egy óraadótanár tartozott. Összesen heten rendelkeztek a Zeneakadémián szerzett tanári képesítéssel, öten pedig tanítási engedéllyel dolgoztak, különféle végzettségek alapján.

\footnotetext{
19 Molnár Imre (1888-1977) zenei író, énekmúvész, énektanár, zenekritikus, a Zenemúvészeti Főiskola tanára; Molnár Antal (1890 - 1983) zenetörténész, zeneszerző és zeneesztéta, brácsamúvész, Kodály Zoltán egykori tanítványa.
} 
Belle igazgatósága idején a tanári kar létszáma jelentősen nem változott, általában 12-13 körül mozgott. Az 1940-41-es tanévről kiadott értesítőben közölt névsorból jól látható, hogy a tanárok nagy része tapasztalt, zeneakadémiai tanári végzettséggel rendelkező zenetanár, sokan közülük már Király-König idejében a zeneiskola tanárai, voltak.

A tantestülethez rövidebb-hosszabb időre óradíjas tanárok is csatlakoztak. Például az 1937-38-as értesítőből kiderül, hogy Baranyi Lilly 1938 szeptemberében kérte a polgármestert, amennyiben zongora szakra a kiírt létszám felett jelentkeznek növendékek, úgy óraadóként vegyék alkalmazásba. Ugyanebben az évben nyújtott be hasonló kérelmet Zucker Hilda okleveles zongoratanár is, ő azonban csak 1945-ben került be a tanári karba (Belle, 1938a.). ${ }^{20}$

Nemcsak az épület 1939-ben történő átalakítása, de a háborús évek is terheket róttak a tanári karra. Belle Ferenc és Perényi Pál többször vonult be katonai szolgálatra, az ő feladataikat ez idő alatt kollégáik látták el. A zeneiskola hangversenytermét a Népmozgalmi Hivatal, egy nagyobb termét pedig a Népiskolai Törzskönyvi Hivatal foglalta el. A tanítás a többi teremben zavartalanul folyt, a hangversenyeket a Tisza Szállóban és a zeneiskola próbatermében tartották. „... (N)övendékeink általános színvonala a megnehezedett élet és családi körülmények dacára sem maradt az előző évekéi mögött. A szülők érdeklődése és ezáltal a növendékek szorgalma és komolysága a már szinte túlterhelt tanárok munkáját is könnyebbé és eredményesebbé tette." - írta Belle Ferenc 1943-ban (Belle, 1943b. 5. o.).

\section{A ZENEISKOLA NÖVENDÉKEI}

Az 1920-as évek végén a zeneiskola növendékeinek száma Lugosi jegyzéke alapján 360 fó körül mozgott, a kimaradókról ez a dokumentum nem közölt adatot. Ebben az időszakban a növendékek zöme már három-négy éve tanult zenét, a növendékek többsége öt-hat éven keresztül folytatta tanulmányait. Lugosi statisztikája szerint tanulmányaik első évében körülbelül a növendékek 30\%-a hagyta abba a zenetanulást, a zeneiskolába felvettek közül a későbbiekben 2\% bizonyult „zeneileg képezhetetlennek”. A tanulók nagy többsége zongorázni tanult, ezután népszerúségben a hegedú következett, ezt követte a gordonka és magánének tanszakon tanulók száma (Lugosi, 1929a. 51-54. o.). ${ }^{21}$

A Belle Ferenc igazgatósága alatt kiadott értesítők alapján a tanulók létszáma egyértelmúen alacsonyabb volt (250-270 fő körül), és lassú növekedést mutatott 1935-1939 között. Az 1939-40. tanévtől érte el vagy haladta meg a növendékek száma a 300-at, az 1942-43. tanévi értesítőben pedig arról számoltak be, hogy a beiratkozott 335 növendék miatt a tanárok nagy része óraszámán felül is vállalt tanítást. Az értesítőkben pontosan megadták a kimaradt növendé-

\footnotetext{
${ }^{20}$ Később,1952-től az újjászervezett, csak alapfokú oktatást nyújtó zeneiskola igazgatója.

${ }^{21}$ Lugosi jegyzéke 1925 és 1928 közötti tanévekről közölt adatokat.
} 
kek számát is. Arról, hogy a növendékek közül hányan bizonyultak „zeneileg képezhetetlennek", az értesítók nem közöltek adatot. Valószínúleg e tanulók számát csökkentette az időközben bevezetett felvételi vizsga is. A hangszerek népszerûségi sorrendje a Belle-korszakban sem változott sokat: legtöbben zongorázni tanultak, ezt követte a hegedú. A magánének szakosok száma ebben az időszakban már megelőzte a gordonkát választókét. A kiadott értesítők külön jelölték a már felsorolt hangszereket és magánéneket választó „rendes” növendékeket és a más szakokon elméleti tárgyakat, nagybőgőt tanuló és zeneóvodába járó „rendkívüli” diákokat, akiknek a száma lényegesen alacsonyabb volt. A „rendkívüli" diákok tandíja is különbözött a „rendes” diákokétól. A nagybőgő szakosok minden díjtól mentesen, teljesen ingyen tanulhattak az intézményben, ez az intézkedést nyilvánvalóan a hangszer kisebb népszerúsége indokolta. A zeneóvodáról már a tanulmány korábbi fejezetében szóltunk. 1935-36-os tanévtől kezdődően a zeneóvodába jelentkezők számát is közölték a „rendkívüli” növendékek között. Az 1936-37-es tanévben jelentkeztek ebbe a csoportba legtöbben, 27-en. Az ezt követő tanévekben a beiratkozók száma csökkent. Végül a képzés az 1940-es évek elejére meg is szúnt, és csak 1945-ben, a konzervatóriummá alakulás előkészületének tekinthetô időszakban indult újra az 1946-ban kiadott értesítő szerint.

\section{ÖsSZEGZÉS}

Az 1935-1944 közötti időszak különféle dokumentumait áttekintve jól látható, milyen külső és belső események alakították a Városi Zeneiskola életét, a történelmi események milyen lépésekre késztették a Szeged zenei életében és zeneoktatásáért dolgozó szakembereket és vezetőket. Belle Ferenc elsősorban Szeged kulturális, azon belül zenei, és zenepedagógiai központi szerepének megerősítsét és megőrzését tûzte ki célul. Munkája nyomán tovább nőtt az intézmény képzésének színvonala, amely hozzájárult a szegedi zeneértő, zeneszerető közönség gyarapodásához, egyben azt is lehetôvé tette, hogy a város zenei együtteseibe egyre színvonalasabb munka folyjon az intézményből kikerülő „amatőr zenészeknek”, zenészeknek köszönhetően .

\section{FELHASZNÁLT IRODALOM}

Antos Kálmán: Az elméleti oktatásról. In: Belle Ferenc dr. (1937): Szeged Szabad Királyi Város Zeneiskolájának 1936-37. tanévi értesítője. Széchenyi Nyomda, Szeged. 12-15.

Belle Ferenc dr. (1935): Szeged Szabad Királyi Város Zeneiskolájának 1934-35. tanévi értesítője. Széchenyi Nyomda, Szeged.

Belle Ferenc dr. (1936a): Szeged Szabad Királyi Város Zeneiskolájának 1935-36. tanévi értesítője. Széchenyi Nyomda, Szeged. 
Belle Ferenc dr. (1936b): Zeneiskolánk jövő feladata. In: Belle Ferenc dr. (1936a): Szeged Szabad Királyi Város Zeneiskolájának 1935-36. tanévi értesítője. Széchenyi Nyomda, Szeged. 7-10.

Belle Ferenc dr. (1937): Szeged Szabad Királyi Város Zeneiskolájának 1936-37. tanévi értesítője. Széchenyi Nyomda, Szeged.

Belle Ferenc dr. (1938a): Szeged Szabad Királyi Város „Liszt Ferenc” Zeneiskolájának 1937-38. tanévi értesítője. Széchenyi Nyomda, Szeged.

Belle Ferenc dr. (1938b): Újabb iskolatipus felé. In: Belle Ferenc dr. (1938a): Szeged Szabad Királyi Város "Liszt Ferenc” Zeneiskolájának 1937-38. tanévi értesítöje. Széchenyi Nyomda, Szeged. 3-6.

Belle Ferenc dr. (1939a): Szeged Szabad Királyi Város „Liszt Ferenc” Zeneiskolája 1938-39. tanévi értesító. Árpád Nyomda, Szeged.

Belle Ferenc dr: (1939b): A zeneiskola új épülete és új programja. In: Belle Ferenc dr. (1939a): Szeged Szabad Királyi Város „Liszt Ferenc” Zeneiskolája 1938-39. tanévi értesítő. Árpád Nyomda, Szeged. 3-5.

Belle Ferenc dr. (1940): Szeged Szabad Királyi Város "Liszt Ferenc" Zeneiskolája 1939-40. tanévi értesító. Árpád Nyomda, Szeged.

Belle Ferenc dr. (1941a): Szeged Szabad Királyi Város "Liszt Ferenc" Zeneiskolája 1940-41. tanévi értesíto". Árpád Nyomda, Szeged.

Belle Ferenc dr. (1941b): A hangversenyélet korszerúsítése. In: Belle Ferenc dr. (1941a): Szeged Szabad Királyi Város „Liszt Ferenc" Zeneiskolája 1940-41. tanévi értesító. Árpád Nyomda, Szeged. 3-4.

Belle Ferenc dr. (1941c): A gyermek és a zene. In: Belle Ferenc dr. (1941a): Szeged Szabad Királyi Város "Liszt Ferenc" Zeneiskolája 1940-41. tanévi értesito”. Árpád Nyomda, Szeged. 5-7.

Belle Ferenc dr. (1942): Szeged Szabad Királyi Város „Liszt Ferenc” Zeneiskolája 1941-42. tanévi értesítő. Árpád Nyomda, Szeged.

Belle Ferenc dr. (1943a): Szeged Szabad Királyi Város "Liszt Ferenc" Zeneiskolája 1942-43. tanévi értesíto". Árpád Nyomda, Szeged.

Belle Ferenc dr. (1943b): Beszámoló. In: Belle Ferenc dr. (1943a): Szeged Szabad Királyi Város "Liszt Ferenc” Zeneiskolája 1942-43. tanévi értesítő. Árpád Nyomda, Szeged. 3-6.

Belle Ferenc (1976): Emlékeim. Somogyi-könyvtári múhely. 76. 1-2. sz. 1-35.

Gévayné Janurik Márta és Kerekné Fekete Éva (2013): A Zenedétől a Zenemüvészeti Karig. Fejezetek a szegedi zeneoktatás történetéből dokumentumok és képek tükrében. Litofilm Nyomda, Szeged.

Kerek Ferenc (2003): A stájer havasoktól Szegedig. Doktori értekezés. Liszt Ferenc Zenemúvészeti Egyetem, Budapest.

Kollár Pál (1947): Szeged Város „Liszt Ferenc” Zeneiskolája 1946-47. tanévi értesítō. Haladás Nyomda, Szeged.

Kristó Gyula és Farkas József szerk. (1985): Szeged története II. 1686-1849. Szeged Megyei Városi Tanács megbízásából: Somogyi Könyvtár, Szeged. 
Lugosi Döme (1929a): A zenemüvelés Szegeden. Szeged szab. kir. Város Jelentése a Vallás és Közoktatásügyi Miniszterhez. Szeged Szab. Kir. Város Közönsége, Szeged.

Lugosi Döme (1929b): A szegedi zenekultúra története. Muzsika. Zenemüvészeti, zenetudományi és zenekritikai folyóirat. Felelős szerk: Papp Viktor, 111.sz. 10-51.

Muzsika. Zenemüvészeti, zenetudományi és zenekritikai folyóirat. Felelős szerk. Papp Viktor 1929. 111. szám

Pappné Kopasz Ildikó (2009): A város zenészei. A komolyzene szegedi követei a kezdetektől 1994-ig. In: Szegedi muzsikusok. Írások a város szimfonikusainak évtizedeiből. (Szerk. Tandi Lajos), Bába és Társai Nyomda, Szeged. 7-15.

Reizner János (1900): Szeged története 3. kötet. http: //www . bibl .u-szeged . hu/reizner/reizner.htm online: 2015. aug.

Simkó Mária (1936): A zeneovoda célja. Szeged Szabad Királyi Város Zeneiskolájának 1935-36. tanévi értesítője. Széchenyi Nyomda, Szeged. 11-13.

Tölgyesyné Renyé Anna (1939): Zene előkészítő iskola a legújabb pedagógiai elvek alapján. In: Belle Ferenc dr. (1939a): Szeged Szabad Királyi Város „Liszt Ferenc" Zeneiskolája 1938-39. tanévi értesitó. Árpád Nyomda, Szeged. 15-16. 